\title{
KEELEKONTAKTIDE UURIMISE VÕLU (JA KASU)
}

\author{
ANNA VERSCHIK
}

\section{Sissejuhatus}

$\mathrm{T}$ uleb igati nõustuda Zoltán Dörnyei (2011: 310) arutlusega, et uurimissuuna, -küsimuse, -strateegia, -meetodi jms valik sõltub uurija isikust. Poolnaljatlemisi kirjutab ta vestlusest kolleeg Kathy Daviesega, kus viimane nentis, et kvalitatiivsete ja kvantitatiivsete meetodite viljelejad on erinevat tüüpi inimesed. Z. Dörnyei märkab, et mida rohkem ta uurib ja mida rohkem kogemusi tal tekib, seda rohkem kasvab temas veendumus, et tõepoolest, lähenemise jms valiku taga pole tihti niivõrd teadusfilosoofilised kaalutlused kui see, kes antud teadlane on ja mis teda huvitab.

Pinge kvantitatiivse ja kvalitatiivse lähenemise vahel keeleteaduses pole uus (vt nt Duff 2002: 13). Mõned keeleteadlased lähevad isegi kaugemale ja pinge asemel räägivad koguni paradigmasõdadest (paradigm wars); veelgi rohkem näitlikustab probleemi kvalitatiivseid meetodeid kaitsva artikli pealkiri „May I see your warrant, please? Justifying outcomes in qualitative research” („Kas tohiks näha Teie luba? Õigustades kvalitatiivse uurimuse tulemusi") (Edge, Richards 1998). Minu arvates on keeleteaduses olemas veel üks oluline pinge või, pehmemalt väljendudes, veelahe, mis pole nimetatust sugugi vähem tähtis: ükskeelsuse ja mitmekeelsuse uurimise vahel. Mõlemad võivad olla kvalitatiivsed või kvantitatiivsed (või kombineerida mõlemat lähenemist), kuid maailmavaateliselt on nad üpris erinevad. Ka siin sõltub valik uurija isikust ja tema kalduvustest.

Millegipärast eeldatakse vaikimisi, et ükskeelsus ja n-ö kontaktitus on keele või keelekasutajate jaoks loomulik, markeerimata olek; ometi pole ühtegi keelt, mis poleks kontaktis teistega, ja pole ühtegi ühiskonda, kus poleks mitmekeelseid inimesi. Ka Eesti ühiskonnas on ükskeelseid üha vähem. Ükskeelse mõõdupuu (monolingual bias) ohtudest seal, kus kõnelejaskond ei ole ükskeelne, on kirjutanud paljud autorid (vt nt Backus 1999; Pavlenko 2005: 1-3). Kujutlusel ükskeelsusest ja kontaktitusest on aga üldise keeleteooria (ja ka rakenduslingvistika) jaoks rasked tagajärjed, sest keskkond pole kunagi homogeenne ja mitmekeelsuse puhul ei ole ka alati selge, mis on emakeel. Nagu Daniel Everett (2004) selgitab, on siingi tegemist eeskätt uurija häälestusega: näiteks Noam Chomskyle ei meeldinud omal ajal välitöö ja etnograafilised meetodid, mida viljelesid Ameerika keeleantropoloogid ja strukturalistid.

Sellest järeldub, et kuigi see, millele tähelepanu pöörame ja mida lõpuks uurima hakkame, on tingitud mitmest asjaolust (hariduslik taust, teema läbiuuritus üldse, teaduslik kliima vastavas ülikoolis/riigis, kolleegide/juhendajate olemasolu vms), ei ole maailmavaade, huvi ja konkreetse isiku teaduslikud kalduvused sugugi viimasel kohal. Mitmekeelse inimesena ja mitmekeelsuse uurijana näen meie ümber ja kipun pidama tähtsamaks just keelekontakte, 
kontaktidest johtuvaid keelemuutusi, mitmekeelsete kõnelejate keeleressursside kasutamist jms.

Eesti on keelekontaktide uurimiseks atraktiivne koht mitmel põhjusel:

- sotsiolingvistiline olukord erineb paljuski läänemaailma omast, millega kontaktlingvistika on valdavalt tegelnud;

- Eesti on väike, seega hõlpsamini haaratav, saab uurida keelekontakte ka regionaalses, põlvkondlikus jms perspektiivis;

- postsovetliku keeleruumi esindajana on Eesti (koos teiste Balti riikidega) mõnevõrra erandlik: on näha, kuidas keelesuhted ja hierarhiad on muutunud ja mis mõju on see avaldanud (ja avaldab praegugi) nt vene keelele.

Järgnevalt toon mõned näited ja pakun neile tõlgendust, kirjeldan mitmekeelset isikut kui muutuste tekitajat ja edasiviijat (n-ö mõjuagendi rolli), selgitan kahe kontaktlingvistilise mudeli näitel, millised mehhanismid toimivad. Lõpetuseks räägin kontaktlingvistika tähendusest ja rakendusvõimalustest, samuti seostest naaberdistsipliinidega.

\section{Mitmekeelne isik kui mõjuagent. Mikro- ja makrotasand}

Järgmised näited on pärit erinevatest suhtlussituatsioonidest. Keelekasutajate sugu, vanus, ilmselt ka töökoht, keeleline repertuaar ja sotsiaalsed võrgustikud on kõigis näidetes erinevad. Näites 1 noomib nördinud ema oma 3-4aastast poega:

(1) Как ть себя ведешь, täitsa outrageous!

'kuidas sa käitud, täitsa kohutav!'

Lauses on kolme keele leksikaalseid elemente (ehk kahes kohas toimub koodivahetus). Kuna kõnelejast ei ole midagi teada, ei julge teha oletusi tema tausta kohta, kuid vene keelt räägib ta ilma aktsendita. Eesti ja inglise keele elemente on ütluses liiga vähe, et teha kindlaid oletusi nende keelte oskuse kohta, kuid inglise outrageous 'kohutav' kõlas selge vene aktsendiga. Üleminekud toimusid sujuvalt, kõneleja oli tõepoolest endast väljas ja ütles selle lause kiiresti, sõnavaliku üle pikemalt mõtlemata. Situatsioon polnudki see, kus oleks võinud jääda pikalt arutlema ja sõnu otsima. Selge, et tegemist ei ole nn leksikaalse lüngaga (kui vaste teises keeles ei tule meelde või puudub sootuks). Võib oletada, et ütluse põhikeel on vene keel. Miks just täitsa ja outrageous on muus keeles? Põhjuseid võib olla mitu.

Esiteks ei muuda eesti- ja ingliskeelsed elemendid ütluse sisu ja tähendust (oleks täiesti mõeldav pelgalt Как ть себя ведешь 'kuidas sa käitud'), vaid pigem modifitseerivad ütlust, väljendades kõneleja suhtumist. Selliseid keeleühikuid nimetatakse erinevates traditsioonides erinevalt, aga kontaktlingvistikas üsna tihti diskursuspragmaatilisteks partikliteks/sõnadeks (discoursepragmatic particles/words). Yael Maschler (1994) räägib partiklite n-ö metalingvistilisest funktsioonist: suhtumise väljendamine, ütluste omavahelised seosed (mööndus, vastandus). Võrdlus teiste kontaktsituatsioonidega aga näitab, et diskursuspragmaatilised partiklid (mille hulka kuuluvad ka sidesõnad, modaalsõnad, interjektsioonid jt) on väga tihti kopeeritavad/laenatavad. Näiteid võib tuua lähedalt (läti un 'ja' saksa laenuna) ja kaugemalt (inglise par- 
tiklid USA serbia keeles, vt klassikaliseks saanud kirjeldus Salmons 1990). Huvitatud lugeja võib selles hõlpsasti veenduda, lugedes Jim Hlavaci (2006), Leelo Keevalliku (2006a, 2006b), Raihan Muhamedowa (2009), Suzanne Wertheimi (2003) uurimusi. Eesti venelaste kõnes esineb perioodiliselt eesti diskursuspragmaatilisi partikleid (tere, musi-kalli, eks ole, muidugi jm). Seega on nähtus üsna levinud; sügavamad põhjused on ilmselt kognitiivsed (teatud tähendusi kandvad lekseemid on hõlpsamini laenatavad) ja kommunikatiivsed (kontrast, tähelepanu juhtimine). Mõned autorid räägivad teatud kognitiivsest konvergentsist (Salmons 1990) või fusioonist (Matras 1998). Ülevaate diskursuspragmaatiliste sõnade kõrge laenatavuse erinevatest seletustest annab Yaron Matras (1998, 2009: 138-145).

Teiseks põhjuseks võib olla just teadlik kontrast: järsk üleminek köidab tähelepanu ja antud juhul rõhutab olukorra tõsidust (pole teada, kas laps sai aru eesti ja inglise sõnadest, kuid ta tajus, et ema ei tee nalja).

Nagu öeldud, kõneleja kohta võib teha vaid oletusi. Võimalik, et tema pere on mitmekeelne ja et seal kasutatakse kahte-kolme keelt. Näide võib tunduda mõnevõrra erandlik, sest koodivahetus toimub kaks korda kolme keele vahel; samas pole selles asjaolus vähemalt Tallinna oludes midagi enneolematut, kuigi koodivahetus kahe keele vahel on ilmselt sagedam ja tundub tavapärasem. Võime jälle rääkida kolmest kohalikust keelest, ainult saksa keele asemel on nüüd inglise keel.

Näide 2 koosneb ainsast pealtnäha eesti sõnast, kuid tähelepanelikumal vaatlusel selgub, et lugu on keerulisem:

(2) vorstima 'oma positiivseid emotsioone (kärarikkalt ja tähelepanu köitvalt) välja elama'

Vaatamata eesti tüvele vorst- ja eesti verbi morfoloogilistele tunnustele, on sõna vorstima eeskuju vene noortekeelne колбаситься (ülaltoodud tähendusega), mis on omakorda tuletatud sõnast колбаса 'vorst'. Kuigi vene колбаситься on tänapäeva vene kõnekeeles üldlevinud, ei saa sama öelda vorstima kohta eesti keeles. Näite on mulle toonud mitmed Tallinna Ülikooli üliõpilased kursuse „Erikursus kakskeelsusest” iseseisva töö raames, seletades, et sõna on kasutusel segasõpruskondades, mis koosnevad eesti ja vene keele kõnelejatest. Keelend olevat seega üsna piiratud levikuga. Et колбаситься on vene klubikultuuris tuntud, siis eestlastega vastaval teemal rääkides tunti vajadust millegi analoogse järele. Kuna aga täpne vaste puudub, ei meenu kohe või on kõnelejatele teadmata, siis on leidlikud kakskeelsed loonud verbi vorstima ja seletanud sõpruskonda kuuluvatele eestlastele selle tähendust.

Näide 3 ei sisalda pealtnäha ühtegi eestikeelset elementi ja on täiesti venekeelne:

(3) Ущел в банкрот 'läks pankrotti'

Sellele vaatamata ei ole näites 3 toodud väljend ükskeelsele venelasele arusaadav või tundub veider, sest venekeelne vaste on обанкротился 'läks pankrotti' ehk tuletis nimisõnast банкpom 'pankrot'. Eeskujuks on antud juhul eesti püsiväljend läks pankrotti; vene keelele iseloomuliku tuletusmehhanismi asemel moodustatakse ühend, mis toimib eesti verbiühendiga sarnaselt. 
Näide 3 on pärit venekeelsest blogist; blogija on seda väljendit kasutanud mitu korda ja eri aegadel, mis osutab juba teatud juurdumisele idiolekti tasandil. Tegemist on kirjaliku tekstiga, mis ei ole nii spontaanne nagu suuline suhtlus. Seega ei ole selline keelekasutus juhuslik. Teatud terminoloogilises raamistikus nimetatakse taolisi juhtumeid tõlkelaenudeks (vt lähemalt Backus, Dorleijn 2009; Backus 2010). Nagu Ad Backus (2010) selgitab, on tõlkelaenudel tohutu roll keelemuutuses, mis aga jääb tihti märkamata, sest niisugustel juhtudel ei kasutata ühtegi teise keele morfeemi.

Esitatud kolm näidet on pärit erinevatest suhtlussituatsioonidest, erinevatelt keelekasutajatelt, erinevatest žanridest. Nad puudutavad erinevaid keeletasandeid ja kontaktnähtusi. Ka mõjusuunad on erinevad. Näide 2 on teadliku muudatuse tulemus (teadlikust muudatusest kui keelemuutuse ühest mehhanismist vt Thomason 1997), ülejäänud ei ole kuidagi ette kavandatud. Samas on neil kõigil mõndagi ühist. Kõik näited on registreeritud Tallinnas noorema põlvkonna keelekasutajate seas. Esimesel juhul ei ole teada nördinud ema kohta kuigi palju, samas on selge, et vene keel on kindlasti üks tema tavakeeltest. Ülejäänud juhtumite puhul on keelekasutajad kindlasti vene emakeelega. Tekib vähemalt kaks küsimust: kas antud muutused jäävad püsima või mitte ja kas nad ka levivad.

Ei ole võimalik sajaprotsendilise täpsusega ennustada, millised kontaktidest johtuvad keelemuutused jäävad kasutusse. Mitmed uurijad on täheldanud, et laenatavuse hierarhias on esikohal kindlasti nimisõnad (vt Backus, Verschik 2012; Field 2002: 38; Matras 2012). Puhtformaalsete kriteeriumide järgi ei ole võimalik eristada koodivahetust ja laenu (vt Zabrodskaja 2009b eesti-vene kontaktide kohta; üldisemalt aga Johanson 2002a), pigem on asi keelendi põlistumises. Selle väitega nõustub ka siinkirjutaja. Ilmselt on nimisõnade n-ö settimise (põlistumise) põhjus nende tähenduses (Backus 2001). Sellepärast on kohalikus vene keele variandis (mõnikord kasutatakse juba nimetust eestivene) juurdunud eesti kultuuri (ka materiaalse kultuuri) ja kohalike reaalidega seotud nimisõnad, mis esinevad mõnikord ka kirjalikes tekstides: haigekassa > хайгекасса, mulgi kapsas > мульги-каnсас, hooneregister > хоонерегистр jne. Nimisõnadega võrreldes on verbide tähendus abstraktsem, verb on semantiliselt vähem spetsiifiline (vt Verschik 2007). Samal ajal tuleb arvestada, et semantiline spetsiifilisus, ainulaadsus jms on suhteline: hooneregister on spetsiifilisem kui lihtsalt register, hoone on spetsiifilisem kui maja jne. Kuigi verbid on üldiselt vähem spetsiifilised kui nimisõnad, on ka erandeid. Mõned verbid, nagu juba mainitud vorstima, on tähenduselt küllalt eripärased, mis võib kergendada nende põlistumist, vähemalt teatud kasutajaskonna seas.

Näites 1 figureerivad diskursuspragmaatilised sõnad, mida tavapärastes laenatavuse hierarhiates millegipärast ei mainita, kuid mille levik ühest keelest teise on üldtuntud. Erinevalt täistähenduslikest sõnadest ei saa siin rääkida konkreetsest või abstraktsest tähendusest. Tuletame meelde Maschleri (1994) pakutud metalingvistilist funktsiooni: need sõnad kujundavad ja suunavad vestlust, selle sisu muutmata. Nõnda võib oletada, et levida võivad diskursuse organiseerimise seisukohalt (pragmaatiliselt) olulised elemendid (vt ka Matras 2005; samuti Vaba 2011 inglise-eesti juhtum). Need elemendid aitavad seostada ütlust teistega, osutuvad ütluste, teemade jms vahelistele suhetele. Teoreetiliselt ei ole põhjust, miks näiteks eesti täitsa ei võiks muu- 
tuda venelaste kõnepruugis tavaliseks, nagu on juba muutunud selge, muidugi ja mõned eesti partiklid.

Nagu Yaron Matras (2012: 23) mainib, tekivad sellised uuendused sõnavaras sellepärast, et omakeelset vastet ei looda, sest selle järele ei tunta vajadust. Kui uuendus eksisteerib paralleelselt põlise elemendiga, siis on neil erinevad konnotatsioonid (nad kuuluvad erinevatesse stiilidesse, tähendused on pisut erinevad jms). Sellel kõigel on ka kommunikatiivne eesmärk, sest kuulajad tajuvad teise keele elementide kuuluvust n-ö mujale, nõnda tekib kontrast, mis, tõsi küll, võib aja jooksul maha kuluda. Siis ei tundu uuendus enam uuendusena ja sõna muutub laenuks traditsioonilises mõttes, olles nüüd ka ükskeelsete inimeste keeleressursside osa.

Morfosüntaksi tasandil toimuvaga on keerulisem (näide 3). Siin pole tegemist keeleainese (tähenduse ja vormi) kopeerimisega, mis on tihtilugu teadlik. Reprodutseeritakse hoopis teatud kollokatsiooni ja selle terviklikku tähendust, mis pole komponentide üksiktähenduste summa. Kui reprodutseeritakse malle, kollokatsioone, tähendusi jms, siis on uuendus pigem alateadlik, keelekasutajad reeglina ei pruugi seda tähele panna. Matras (2009: 236) seletab, milliseid kategooriaid laenatakse „kogu täiega” (nii vorm kui ka tähendus) ja milliseid osaliselt (ainult tähendus, funktsioon, sõnajärg jms). Viimasesse rühma kuuluvad artiklid, aeg ja aspekt, käänete funktsioonid. Üldisemalt võttes tähendab see, et A-keeles juba olemasolevad elemendid saavad B-keele vastavate elementide funktsioonid ja tähendused, nt mas-vorm hakkab eesti keeles levima inglise progressiivi mõjul kontekstides, kus seda varem ei kasutatud (Metslang 2006; laiemalt vt Heine, Kuteva 2005, kontaktist johtuv grammatisatsioon).

Traditsiooniliselt on keeleteaduses eristatud sünkrooniat ja diakrooniat ning muutusi kõnes ja muutusi keeles (Weinreich 1953). Kontaktlingvistikas räägitakse mõnikord muutusest rangemas tähenduses, pidades silmas midagi, mis on juba juurdunud ja levinud. Siiski pole võimalik öelda, kus lõpeb sünkroonia ja algab diakroonia. Muutused Eesti vene keeles (ka morfosüntaksis) hakkasid tekkima siis, kui oli tekkinud arvestatav hulk eesti keelt kasutavaid venelasi, seega mitte enne taasiseseisvumist. Kas 20 aastat on sünkroonia või juba diakroonia? Kui uuenduslik sõna, vorm, tähendus jms on registreeritud, tähendab see, et selle levik ja üldistumine on potentsiaalselt võimalik. Mõni uuendus ei põlistugi ja hääbub varem või hiljem. Matras (2009: 40) rõhutab, et nii sünkroonsed nähtused kui ka need, mida võib nimetada keelemuutuseks, sünnivad kakskeelse kõneleja keelelisest käitumisest. Seega on tegemist ühe ja sama protsessiga läbi aegade; pole põhjust arvata, et mitmekeelne kognitsioon ja sellest johtuv keeleline käitumine oli kaugemas minevikus oluliselt teistsugune kui praegu.

Selles suhtes tuleb nõustuda Matrasiga, kes on kirjutanud üksikisiku otsustavast rollist keelemuutuses (Matras 2009: 310 jj). Tõsi küll, juba Uriel Weinreich (1953: 71) mainis, et keelekontaktide toimumispaik on kakskeelse inimese aju, kuid samal ajal läbib kogu ta raamatut jaotus „interferentsiks kõnes ja keeles”. Kõik algab ikkagi mitmekeelse keelekasutaja kognitsioonist, üksikisik on n-ö mõjuagent. Mõistlik tundub Matrasi arutluskäik, et traditsiooniline vahetegemine individuaalse ja ühiskondliku mitmekeelsuse vahel varjutab asjaolu, et kontaktidest johtuvate muutuste mehhanisme tuleb otsida hoopis mikrotasandil, üksikisiku konkreetsetest diskursuse strateegiatest 
ja mitte niivõrd makrotasandi sotsiaalsetest protsessidest (Matras 2009: 310). Matras (2009: 68) eelistab rääkida pigem mitmekeelse kõneleja keelelisest repertuaarist (language repertoire) kui eraldi keelesüsteemidest. Mitmed uurijad (Clyne 2003; Backus 1999; Thomason 1997 jpt) on näidanud, et analüüsimisel ei saa lähtuda kahest diskreetsest, abstraktsest keelesüsteemist ja et mitmekeelsed keelekasutajad produtseerivad midagi uut, mis ei ole võimalik kahes eraldi võetud ükskeelses keelevariandis (vt ülevaadet Zabrodskaja 2009b: 28-20). Siia tuleb lisada keeleline loovus, mis on eriti ettearvamatu, samas kättesaadav võte nii kakskeelsele lapsele üsna varases eas kui ka keeleõppijale (meenutagem verbi vorstima).

\section{Keeleaines vs. mallid. Kahe mudeli võrdlus}

Eelmises alajaotuses oli juba juttu ainese ja vormi/funktsiooni kopeerimisest. Need on ühe medali kaks külge. Traditsiooniliselt on kontaktlingvistikas vaadeldud eraldi grammatika ja semantika tasandi muutusi (konvergents, tõlkelaen, tähenduslaen, kontaktidest johtuv grammatisatsioon jms) ning muutusi, kus figureerib n-ö võõras vormi-tähenduse kompleks (laenamine, koodivahetus jms). Nagu näha, erineb terminoloogiline raamistik ka sõnavara ja grammatika nähtuste käsitlusel. See tekitab probleeme nii deskriptiivsel tasandil kui ka teooria arendamises.

Koodivahetuse uurimises on järk-järgult juurdunud arusaam, et lineaarsed piirangud (vastuolu kahe keele morfosüntaksi vahel) ei tööta universaalselt, sest teise keele ainese sissetoomine võib ühtlasi kaasa tõmmata teise keele morfosüntaktilisi suhteid. Kuid isegi üpris keerukad koodivahetuse mudelid, nagu Carol Myers-Scottoni 4M mudel (Myers-Scotton 2002: 22), ei tegele morfosüntaksis toimuvaga: Myers-Scotton ei ole terminoloogias järjekindel ning kasutab terminit „liitmaatrikskeel” (composite matrix language) mõnikord juhtudel, kus leksikaalsed struktuurid on pärit kahest keelest, teinekord aga juhtudel, kus pole ühtegi teise keele morfeemi ja tegemist on pealtnäha ükskeelse ütlusega (nagu näide 3; vt lähemalt eesti keeles Zabrodskaja 2009b: 62).

Pieter Muyskeni nn kolmnurga mudel (triangle model, Muysken 1995, 2000) rühmitab juhtumid, kus koodivahetus põhjustab morfosüntaktilisi muutusi, ühilduva leksikaliseerumise (congruent lexicalization) sildi alla, kuid veelahe sõnavara ja morfosüntaksi vahel siiski säilib. Bernd Heine ja Tania Kuteva aga tõmbavad veelgi järsema piiri ja ütlevad, et tegelevad ainult grammatikas aset leidvate nähtustega (Heine, Kuteva 2005: 2).

Kahe viimase kümnendi jooksul on pakutud kaht teoreetilist mudelit, mis kirjeldavad ühes teoreetilises raamistikus kõiki kontaktidest johtuvaid nähtusi. Need on Lars Johansoni koodikopeerimise mudel (Johanson 1993, 2002b; eesti keeles vt Praakli 2009; Vaba 2011; Verschik 2007) ning Yaron Matrasi ja Jeanette Sakeli MAT- ja PAT-mudel1 ${ }^{1}$ (Matras, Sakel 2007; hilisemad modifikatsioonid Matras 2009, 2012).

1 Olen tänulik Martin Ehalale mudeli eestikeelse terminoloogia arutelu eest. 


\subsection{MAT- ja PAT-mudel}

Kuigi ka Heine ja Kuteva (2005: 2) kasutavad terminit „replikatsioon” (replication), ei tee nad seda süstemaatiliselt. Matrasi ja Sakeli mudelis on see aga keskne mõiste. Mudel kirjeldab nii sõnavaras kui ka morfosüntaksis, semantikas jm toimuvat protsessi replikatsioonina (jäljendamisena). Siin on kaks võimalust: kas toimub keeleainese replikatsioon (matter replication ehk MATreplication; edaspidi MAT-replikatsioon), mis haarab nii vormi kui ka tähendust, või malli replikatsioon (pattern replication ehk PAT-replication, edaspidi PAT-replikatsioon), kus reprodutseeritakse ainult tähendust, elementide järjestust, kombineerimisreegleid jne, kuid mitte vormi ja tähenduse tervikut. MAT-replikatsioon vastab traditsioonilises terminoloogias umbkaudu laenudele ja koodivahetusele, PAT-replikatsioon hõlmab mitmesuguseid juhtumeid, nagu tõlkelaen, konvergents, struktuuri muutus, sõnajärg jms. Uus on aga mõlema käsitlus ühe ja sama protsessina ehk replikatsioonina.

Nagu juba mainitud, on juhtumeid, kus on oodata pigem MAT-replikatsiooni, ja selliseid, kus on oodata pigem PAT-replikatsiooni. Matras (2012) tutvustab sotsiaalsete ja struktuuriliste tegurite koosmõju. Näiteks grammatiliste morfeemide MAT-replikatsioon on haruldane (mõni väidab, et absoluutselt võimatu, päriselt siiski nii ei ole, vt Verschik 2007). Samal ajal on PAT-replikatsioon grammatiliste morfeemide puhul tavaline.

Kui MAT-replikatsioonil on olemas kommunikatiivsed funktsioonid (vt eelnevate näidete analüüsi), siis PAT-replikatsiooni puhul on mängus midagi muud. Miks siis teise keele malle, reegleid jms jäljendatakse? Matras ja Sakel (2007: 230) seletavad PAT-replikatsiooni mehhanismi. PAT-replikatsiooni võimaldab eelkõige polüseemia (lisaksin veel mitmefunktsionaalsuse): ühes keeles on ühel grammatilisel sõnal kaks funktsiooni/tähendust, mille eeskujul laiendatakse teise keele vastava sõna funktsioone (nt interrogatiivpronoomen on ühtlasi relatiivpronoomen ja seda suhet reprodutseeritakse keeles, kus mainitud pronoomenid on erinevad lekseemid, vt Heine, Kuteva 2005: 113-114).

PAT-replikatsioon toimub tavaliselt teadvustamata, siin ei saa rääkida kommunikatsioonistrateegiast. Kõneleja tõmbab kahe keele mallide vahel paralleele, vastavusi, teisisõnu tuvastab sarnasusi (see osutubki võimalikuks polüseemia tõttu). Teatud omadused mängivad otsustavat rolli (pivotal role). Neid omadusi omistatakse keeles juba olemasolevale elemendile. Näide 4a on pärit venekeelsest blogist:

(4а) Разница от частного сектора хищь в том... 'erinevus erasektorist on vaid selles...'

Blogist selgub kõneleja taust ja keeleline profiil, mis on antud juhul eelis, sest lubab teha kindlamaid järeldusi. Blogija oskab eesti keelt (on riigiametnik, kellelt nõutakse üpris kõrget keeleoskustaset); see ongi tema töökeel. Ta on keeleliselt teadlik, arutab tihti eesti sõnade, väljendite või isegi grammatikareeglite üle. Näites 4a jäljendab ta eesti malli erinevus / erinema + seestütlev. Otsustavaks osutub nn separatiivne rektsioon (eraldava kohakäände kasutus). Blogija valib seega vene prepositsiooni om, mis omakorda tingib vene genitiivi kasutust. Vene ühiskeeles on teistsugune rektsioon: 
(4b) Разница с частныл сектором sõna-sõnalt: 'erinevus erasektoriga'

Konkreetse PAT-replikatsiooni edasine saatus sõltub sellest, kas kaasvestlejad mõistavad ja aktsepteerivad seda. Vaadeldaval juhul ei järgnenud teistelt blogijatelt prepositsiooni- ja käändevaliku kohta ühtki kommentaari. Aktiivsed kommenteerijad on sarnase keelelise profiiliga. Väga võimalik, et nad ei täheldanudki midagi erakordset.

PAT-replikatsioon katab päris laia hulga nähtusi: tõlkelaenudest, kus muutub sõnade tähendusmaht ja kollokatiivne potentsiaal (s.o tekib uus kollokatsioon) kuni struktuurimuutusteni (vt ka Backus, Dorleijn 2009). Nt eesti keeles viimasel ajal levinud tüdruksõber ja poiss-sõber (vastavalt < ingl girlfriend ja boyfriend) on prototüüpsed tõlkelaenud. Näide 3 on piiripealne juhtum: kuigi otseselt ei ole vastuolu vene ükskeelse grammatikaga, on sõnade kombinatsioon võimatu (verb yŭmu ei ole kombineeritav nimisõnaga банкрот, mis vene keeles tähendab ainult pankrotti läinud inimest või firmat). Samuti on tegemist ühise internatsionalismiga. Näide 5 seisab aga juba lähemal struktuurimuutusele, kuigi ei saa öelda, et uuenduslik separatiivne rektsioon (läbi lugema + seestütlev) on algupärase staatilise rektsiooni (vn nрочumamb 'läbi lugema' + lokatiiv, küsimus kus?) välja tõrjunud, või isegi seda, et uuendus on üldlevinud kõigi venekeelsete hulgas:

(5) Кстати, оттуда же прочитала 'muide, sealtsamast lugesingi läbi'

Nagu näeme, on näide 5 rektsiooni valiku poolest sarnane näitega $4 \mathrm{a}$. Esialgu võib ettevaatlikult nentida, et teatud eesti kohakäänetega konstruktsioone reprodutseeritakse ja et see replikatsioonijuhtum ei esine üksnes ühes mikrokogukonnas, vaid laiemalt.

Mudel on funktsionaal-kognitiivne: replikatsiooni seletatakse ühelt poolt keelekasutaja kommunikatiivsete vajadustega, teiselt poolt kognitiivse koormuse leevendamisega.

Vaatleme järnevalt teist, koodikopeerimise mudelit, mis erineb eelmistest mudelitest vähemalt ühe olulise täienduse poolest.

\subsection{Koodikopeerimise mudel}

Koodikopeerimise mudelit on eesti keeles ulatuslikult tutvustatud (Verschik 2007; Praakli 2009; Vaba 2010, 2011; Paljasma 2012). Meenutagem põhiseiku.

Lars Johanson loobub traditsioonilisest terminoloogiast, nagu „laen”, „laenamine”, „koodivahetus”, „koodisegu” jms. Ta põhjendab seda nii, et keel, kust laenatakse, ei jää millestki ilma ja laenu ei pea tagastama. „Laen” elab n-ö oma elu. Ei ole võimalik eristada formaalsetel kriteeriumidel (nagu morfosüntaktiline integratsioon või selle puudumine) leksikaalset laenu ja ühesõnalist koodivahetust, asi on pigem konventsionaliseerumise astmes (täpsemalt vt Zabrodskaja 2009a).

Nagu MAT- ja PAT-mudelis, nähakse siingi üht põhiprotsesssi, mida nimetatakse koodikopeerimiseks (code-copying). Kopeeritakse mudelkeelest ehk -koodist põhikeelde ehk -koodi. Mudel- ja põhikoodiks võib olla nii esimene kui ka teine keel (vastavalt K1 ja K2). Kopeerimine on mõlemasuunaline (K1 > 
K2 ja K2 > K1). Kontaktlingvistika tegeleb mõlemaga, kuid põhiliselt siiski teise juhtumiga. Koopial võivad olla alles kõik originaali omadused, kuid koopia pole originaal; nagu öeldud, kopeeritud element toimib edasi juba põhikeeles ja selle „saatus” ei ole sama, mis originaalil mudelkeeles.

Igal elemendil on nelja tüüpi omadusi: materiaalsed, semantilised, kombinatoorsed ja sageduslikud. Vastavalt sellele, kas kopeeritakse kõiki omadusi või ainult mõningaid, võib rääkida kopeerimisastmest. Kopeerida võib kõiki omadusi, tulemus on täielik koopia (global copy), mis vastab MAT-replikatsioonile Matrasi ja Sakeli mudelis. Kui aga kopeeritakse üht või mitut, kuid mitte kõiki omadusi, on tulemus valikuline koopia (selective copy). Nagu näha, on valikuliste koopiate klass ulatuslik. Kui Matras ja Sakel (2007) räägivad üldistatult PAT-replikatsioonist, siis Johansoni (1993, 2002a) mudel lubab iseloomustada konkreetselt, kas tegemist on semantilise jne koopiaga või näiteks korraga semantilise ja kombinatoorse koopiaga, nagu näites 6 :

(6) квартирный дом < kortermaja

Siin pole võimalik eraldada semantilise terviku kopeerimist ja elementide kombinatsiooni kopeerimist. Vene ühiskeeles on kasutusel многоквартирный дом 'mitmekorteriline maja'; võib mainida ka konkreetse korterite arvu: nt двадиатиквартирный дом 'kahekümne korteriga maja'. Näide 6 tekitaks ükskeelsel venekeelsel küsimusi, sest selline sõnaühend ei tähenda vene keeles midagi. Tegemist on eesti liitsõnaga, mida kohalikus vene keeles kopeeritakse ulatuslikult, nii täielikult kui valikuliselt (Verschik 2004).

Kombinatoorse koopia kui omaette tüübi eristamine aitab paremini märgata seda, mis toimub nn mitmesõnaliste üksustega (multi-word items): analüütiliste vormide, püsiühendite, idiomaatiliste väljendite jms kopeerimist. Juba definitsioonist on selge, et kombinatsioonist saab rääkida vaid mitme elemendi puhul. Siia kuulub rektsioonimallide kopeerimine. Kõneleja on venelasest ajateenija, kes räägib sellest, et parem on läbida teenistus kas enne või pärast kõrgkooli ja mitte selle ajal.

(7) После армии сложно восстановиться на свой курс 'pärast sõjaväge on raske end taastada oma kursusele'

Kõneleja valib latiivse rektsiooni (kuhu?), seega verbile восстановиться 'taastuda, end taastada' järgneb akusatiiv ootuspärase lokatiivi (kus?) asemel (ükskeelne: на своем курсе 'oma kursusel').

Siiani on mudelid sarnased, kuid on veel üks kopeerimise liik, millel pole vastet MAT- ja PAT-mudelis, nimelt segakoopia (mixed copy). Sellisel juhul üks komponent kopeeritakse täielikult ja teine valikuliselt, kuid tegemist on tervikuga, mida ei ole mõistlik (või isegi võimalik) analüüsida komponente eristades. Minu arvates on see liik oluline. Esimest korda puutusin sellega kok$\mathrm{ku}$, uurides vene liitsõnadega toimuvat (Verschik 2004), nagu näites 8:

(8) вийтеномер < viitenumber, vrd номер для ссълки 'number viitamiseks'

Kõnelejad tajuvad, et liitsõna üks komponent on ühine internatsionalism, mis ei ole aga eesti ja vene keeles päris identne. Esimene komponent viite- on 
kopeeritud täielikult. Kuna tegemist on tervikuga (ja asi ei ole ainult liitsõnade konventsionaalses kokkukirjutamises, vaid uues liittähenduses), siis komponente ei saa analüüsida eraldi. Huvitaval kombel ei ole kontaktlingvistikas selliseid juhtumeid kuigi palju käsitletud. Vaid Einar Haugen (1972: 85) puudutab nähtust ääri-veeri ja nimetab neid segalaenudeks (loan-blend).

Püsiväljendite ja -konstruktsioonide puhul on eriti selgelt nähtav semantiline tervik. Kui näite 8 puhul on olemas ükskeelne vaste номер для ссьлки 'viitenumber', siis näites 9 on kopeeritud püsiväljend, millel pole vene keeles vastet:

(9) получить эксмат 'eksmatti saama'

Täielikult on kopeeritud эксмат < eksmatt, valikuliselt получить < saama. Sellist väljendit vene keeles ei ole, samuti ei ole midagi, mis vastaks eesti nimisõnale eksmatt. Väljend ta sai eksmati on konventsionaalses vene keeles его исключили 'ta arvati maha/välja'; seega loogika on teine ja verb väljendab seda, mida eesti keeles väljendab ühend. Et eesti keeles on nimisõnaline komponent eksmatt see, mis teeb väga üldise tähendusega verbist spetsiifilise, siis on ootuspärane just selle täielik kopeerimine. Ainulaadse, vene keelest puuduva üksuse eksmatt kopeerimine „tõmbab kaasa” ka verbi kopeerimise.

Kristiina Praakli (2009: 118, 140 jj) kirjutab segakoopiatest Soomes elavate eestlaste keeles: nt tummaihoinen 'tumedanahaline' > tumedaihuline (ihu < sm iho 'nahk'). Sugulaskeelte vahel on segakoopiad ootuspärased, sest materiaalne sarnasus soodustab igasugust kopeerimist, kuigi pole kopeerimise tingimatu eeldus. Marja Vaba (2010: 21) omakorda märgib, et kopeerimisel inglise keelest eesti keelde esineb samuti segakoopiaid: rushjob > rush-töö 'töö, millega on väga kiire'. Segakoopiad väärivad rohkem tähelepanu; nad ei ole kõik ühesugused ja tulevikus oleks soovitatav välja töötada nende tüpoloogia. Segakoopia näitlikustab asjaolu, et selge eristus vormi ja funktsiooni/ malli kopeerimise vahel ei ole alati võimalik.

Kopeerimise põhjuste hulgas mainib Johanson (2002a) atraktiivsust: mõne omaduse või elemendi kopeerimine on tõenäolisem (võib rääkida selle kõrgest kopeeritavusest). Kuid atraktiivsus on suhteline. A-keele omadus võib olla B-keele jaoks atraktiivne, kuid ei pruugi seda olla C-keele jaoks. Atraktiivsuse kontseptsioon on Johansonil pigem visand; ilmselt on atraktiivsus erinev ka erinevate koopeerimisastmete jaoks. Paistab, et spetsiifiline tähendus soodustab täielikku kopeerimist ja üldine tähendus/kõrge sagedus soodustab omakorda valikulist kopeerimist (täpsemalt sellest Backus, Verschik 2012).

\subsection{Mudelite võrdlus}

Mõlemad mudelid käsitlevad kõiki kontaktnähtusi ühtses terminoloogilises raamistikus. Tõsi küll, Johanson on oma terminoloogias järjekindlam ega kasuta ebamääraseid termineid, nagu laen; Matras $(2009,2012)$ räägib kord MAT-replikatsioonist, kord laenust.

Oluline on, et kumbki mudel ei põhine formaalsetel kriteeriumitel ega piirangutel. See ei tähenda, et kontaktidest johtuvad muutused on suvalised ja kaootilised, vaid pigem seda, et ei ole võimalik ennustada, mis on kontaktide käigus absoluutselt võimatu. Johanson (2002a) väljendab seda seisukohta eriti selgelt. 
Matrasi ja Sakeli mudelis on erilise tähelepanu all mehhanismid, nimelt otsustava rolliga omaduse tuvastamine PAT-replikatsiooni puhul ja kommunikatiivsed eesmärgid MAT-replikatsiooni puhul. Hilisemates käsitlustes arendab Matras (2009, 2012) funktsionaal-kognitiivset komponenti veelgi. Oluline on üksikkõneleja kui „mõjuagendi” roll.

Johanson ei seleta niivõrd mehhanisme, kuivõrd räägib sotsiolingvistilistest põhjustest ja keelevariantide võimalikust arengust tervikuna, kuid implitsiitselt tunnustab temagi üksikkõneleja rolli. See paistab konventsionaliseerumise kirjeldusest: uuendus on alati esmakordne ja võib potentsiaalselt üldistuda või isegi normiks muutuda (Johanson 2002a: 300-301). On arusaadav, et uuenduse algataja on üksikisik. Tervikuna on Johansoni mudel pigem deskriptiivne (mis ja kuidas toimub), kuid see ei vähenda mudeli väärtust, sest ta on deskriptiivselt korrektne ja paindlik (nende omaduste puudumist võib ette heita mõnelegi ülikeerulisele mudelile).

Oluline erinevus on segakoopia kui eriliigi eristamine. Midagi taolist MAT-ja PAT-mudelis ei ole. Siin peidub teatud oht, sest ei ole teada, kuidas käsitleda selliseid nähtusi, nagu näites 8 ja 9 , mis ei ole keelekontaktide käigus üldsegi haruldased. Veelgi suurem oht on, et need nähtused jäävad sootuks märkamatuks.

Üldistatud kujul on võrdlus esitatud tabelis 1 .

Tabel 1 .

MAT- ja PAT-mudeli ning koodikopeerimise mudeli võrdlus

\begin{tabular}{|c|c|c|}
\hline & $\begin{array}{l}\text { MAT- ja PAT-mudel } \\
\text { (Matras ja Sakel 2007, Matras } \\
\text { 2009, 2012) }\end{array}$ & $\begin{array}{l}\text { Koodikopeerimise mudel } \\
\text { (Johanson 1993, 2002a, } \\
\text { 2002b) }\end{array}$ \\
\hline Mudeli üldkirjeldus & $\begin{array}{ll}\text { - } & \text { funktsionaal- } \\
& \text { kognitiivne } \\
\text { - } & \text { ei põhine piirangutel } \\
\text { - } & \text { lähtub üksikkõnelejast } \\
\text { - } & \text { erinevad } \\
& \text { replikatsiooniliigid } \\
\text { erinevate elementide } & \text { puhul }\end{array}$ & $\begin{array}{ll}\text { - } & \text { sotsiolingvistilisi ja } \\
& \text { struktuurilisi tegureid } \\
& \text { arvestav; esimesed } \\
& \text { neist on esmatähtsad } \\
\text { - } & \text { ei põhine piirangutel } \\
\text { - } & \text { üksikkõneleja roll } \\
& \text { aimatav } \\
\text { - } & \text { atraktiivsus } \\
& \text { (omadused, mis } \\
\text { soodustavad } \\
\text { kopeerimist) }\end{array}$ \\
\hline Protsess & replikatsioon & kopeerimine \\
\hline Tulemus & $\begin{array}{l}\text { ? (täpne termin puudub, pigem } \\
\text { kirjeldav seletus) }\end{array}$ & koopia \\
\hline \multirow{3}{*}{$\begin{array}{l}\text { Replikatsiooni/ kopeerimise } \\
\text { liigid }\end{array}$} & MAT-replikatsioon & täielik koopia \\
\hline & PAT-replikatsioon & $\begin{array}{l}\text { valikuline koopia (semantiline, } \\
\text { kombinatoorne, materiaalne } \\
\text { või } 2-3 \text { omaduse } \\
\text { kombinatsioon) }\end{array}$ \\
\hline & - & segakoopia \\
\hline
\end{tabular}


Matras (2009: 146, 155, 236) mainib Johansoni töid, kuid ei peatu nendel pikemalt. See on imelik, sest mudelite vahel on palju sarnasusi, nende lähtepositsioonid pole üksteisega vastuolus. Pealegi avaldas Johanson koodikopeerimise mudeli esimese versiooni juba 1993. aastal.

\section{Rakendamisvõimalused}

Lugeja võib küsida, miks kõik eelnev on oluline just rakenduslikust vaatenurgast, sest tegemist on teoreetiliste mudelitega. Sellele küsimusele leidub mitu vastust.

Esiteks on ettearvamatu, mis teadmisi saab tulevikus rakendada ja kus täpsemalt. Teiseks, nagu sissejuhatuses mainitud, keelekontaktid ja nendest johtuv keelemuutus pole sugugi marginaalsed: väikese kõnelejaskonnaga keelte puhul, nagu seda on eesti keel, on nad isegi keskse tähendusega. Kui hoolikalt ringi vaadata, on kontaktnähtusi kõikjal: reklaamisiltidel, suulises ja ka kirjalikus suhtluses, internetis. Tihtilugu ei suudeta suhtuda keelemuutustesse ja uuendustesse neutraalselt, käiku lähevad lausa kliinilise alatooniga metafoorid (teise keele mõju kui viirus, nakkus, keele lagunemine jms). Muidugi võib kasutajaskond muutustesse sekkuda ja neid suunata (kas keelekorralduse või oma keelelise käitumise kaudu), kuid puhtaid keeli pole olemas ja võorrmõju täielik väljarookimine ei ole realistlik ega vajalik. Kui kontaktidest tingitud konkreetne muutus juurdub (s.o kõnelejaskond võtab selle omaks), siis paari inimpõlve pärast teavad vaid asjatundjad, et tegemist ei ole „oma” keelendi või malliga. Ekslikult seostatakse kontaktidest johtuvat keelemuutust keelesurmaga, kuigi viimase põhjused on sotsiaalpsühholoogilised (kõnelejad ei soovi mingil põhjusel keelt järgmisele põlvele edasi anda) ja mitte keelesisesed. Ükski keel ei laena end surnuks. Sellest järeldub, et üpris palju arusaamatusi ja ärevust ühiskonnas tekib just sellest, et ei tunta kontaktlingvistika põhitõdesid.

Kolmandaks võib ja peab vaatama seoseid teiste keeleteaduslike distsipliinidega. Siiani on teise keele omandamise uurimine ja kontaktlingvistika vähe kokku puutunud. Uurimisparadigmad ja -meetodid on erinevad, erinevad ka terminoloogiline raamistik ja lähtepunktid. Kuigi kontaktlingvistika ei tegele keeleomandamise rakenduslike ega pedagoogiliste aspektidega, on mõned traditsioonilised kontaktlingvistika huviobjektid just keeleomandamise tulemus: see, mida mõnikord nimetatakse substraadiks, on Thomasoni terminoloogias keelevahetusest tingitud interferents (interference through shift, Thomason 2003) ehk esimese keele sugemed hiljem omandatud keeles, kusjuures uus, muutustega keelevariant on üldistunud vähemalt teatud kõnelejaskonna osas. Nõnda on mitmed jooned (nt fikseeritud rõhk esimesel silbil, soo kategooria ähmastumine) läti liivipärastes murretes just keelevahetuse tulemus (lms > blt). Nn kontaktkeelte (contact languages) puhul on kõneldud, kuigi mitte väga veenvalt, sarnasustest pidžinite tekke ja teise keele omandamise universaalide vahel (nt paralleelid Gastarbeiterdeutsch'i ja araabia keele põhiste varajaste pidžinite vahel, vt ülevaadet: Matras 2009: 283). Läti keele puhul nn õppijakeele omadused on üldistunud; võib aga juhtuda nii, et nad levivad vaid teatud kõnelejaskonnas ja tekivad etnolektid, mis võivad, kuid ei pruugi, mängida identiteedi markeri rolli (nt maroko päritolu immigrantide hollandi keele variant, USA juutide inglise keele variant jms). 
Võrdlemisi uus distsipliin, millega kontaktlingvistikal on potentsiaalseid kokkupuuteid, on päritolukeele omandamine (heritage language acquisition). Sellel on ühisjooni nii esimese kui ka teise keele omandamisega (Montrul 2010: 12). Kui lihtsalt öelda, et immigrantide järeltulijad omandavad oma vanemate keelt halvasti või mittetäielikult, on see liiga ebatäpne. Kindlasti on osaliselt põhjus piiratud sisendis (limited input), kuna päritolukeele kasutussfäär ja -võimalused on tavaliselt väiksemad kui enamuskeele omad. Siiski ei piisa ainult sellest, kui postuleerida piiratud sisend ja sellest tulenev „lihtsustumine”, sest päritolukeele omandamine toimub alati konkreetse teise keele ruumis. Näiteks kas käändeparadigma „kokkukuivamine” USA vene keeles on piiratud sisendi tulemus või mõjub siin sotsiolingvistiliselt domineeriv ja kääneteta inglise keel? Teine näide: kui Austraalia saksa keele variantides on üldistunud täismineviku abiverb haben 'omama' seal, kus on ootuspärane sein 'olema', kas on siis tegemist piiratud sisendiga või inglise keele mõjust johtuva muutusega (inglise keeles on üks täismineviku abiverb have 'omama')? Kellega võrrelda, kui mõne päritolukeele kõnelejate hulgas pole ükskeelseid? Sellepärast tulekski kõrvutada piiratud sisendiga keelemuutuste juhtumeid nendega, kus sisend esimese keele omandamisel ei ole kriitiliselt väike ning keele taastootmine järgmises põlves ei ole ohus, samal ajal aga toimuvad kontaktist johtuvad muutused (nagu näiteks vene keeles Eestis).

Võimalik, et seoseid kontaktlingvistika ja teiste keeleteaduslike distsipliinide vahel leidub veelgi. Rõhutan, et Eesti on tänuväärne koht keelekontaktide uurimiseks. Praktiliselt uurimata on inglise-eesti keelekontaktid (nii eestlaste kui ka siin elavate ingliskeelsete välismaalaste seas), kolme kohaliku keele kontaktid, kontaktid mitmesugustes mikrokogukondades ja palju muudki. Sellest oleks kasu nii Eesti-siseselt (saaksime uusi teadmisi tegelikult toimuvatest keeleprotsessidest) kui ka teooria üldise arengu jaoks.

Artikkel on valminud riikliku programmi „Eesti keel ja kultuurimälu” (20092013) grandi „Vene-eesti ja eesti-inglise koodivahetuse ja koodikopeerimise korpuse koostamine ja haldamine” toel.

\section{Kirjandus}

B a ck u s, Ad 1999. Mixed native languages: a challenge to the monolithic view of language. - Topics in Language Disorders, kd 19, nr 4, lk 11-22.

B a ck u s, Ad 2001. The role of semantic specificity in insertional codeswitching: evidence from Dutch-Turkish. - R. Jacobson (toim), Codeswitching Worldwide II. Berlin, New York: Mouton de Gruyter, lk 125-154.

B a ck u s, Ad 2010. The role of codeswitching, loan translation and interference in the emergence of an immigrant variety of Turkish. - Working Papers in Corpus-based Linguistics and Language Education, nr 5, lk 225-241.

B a c k u s, Ad, D o r l ej n, Margreet 2009. Loan translations versus code-switching. - B. Bullock, A. Jaqueline (toim), The Cambridge Handbook of Linguistic Code-switching. Cambridge: Cambridge University Press, lk 75-93.

B a c k u s, Ad, Ve r s c h i k, Anna 2012. Copiability of (bound) morphology. - L. Johanson, M. Robbeets (toim), Copies versus Cognates in Bound Morphology. Leiden: Brill, lk 123-149. 
C ly n e, Michael 2003. Dynamics of Language Contacts. Cambridge: Cambridge University Press.

D u ff, Patricia 2002. Research approaches in applied linguistics. - R. Kaplan (toim), Handbook of applied linguistics. Oxford: Oxford University Press, lk 1323.

D ö r n y e i, Zoltán 2011. Research Methods in Applied Linguistics. Oxford: Oxford University Press.

E d g e, Julian, R i c h a r d s, Keith 1998. May I see your warrant, please? Justifying outcomes in qualitative research. - Applied Linguistics, kd 19, nr 3, lk 334-356.

E v e r e t t, Daniel 2004. Coherent fieldwork. - P. van Sterkenberg (toim), Linguistics Today: Facing a Greater Challenge. Amsterdam: John Benjamins, lk 114162.

Fi e ld, Frederic 2002. Linguistic Borrowing in Bilingual Contexts. Amsterdam: Benjamins.

H a u g e n, Einar 1972. The Ecology of Language. Stanford: Stanford University Press.

Heine, Bernd, Kuteva, Tania 2005. Language Contact and Grammatical Change. Cambridge: Cambridge University Press.

$\mathrm{H} \mathrm{l}$ a v a c, Jim 2006. Bilingual discourse markers: evidence from Croatian-English code-switching. - Journal of Pragmatics, kd 38, nr 11, lk 1870-1900.

J o h a n s o n, Lars 1993. Code-copying in immigrant Turkish. - G. Extra, L. Verhoeven (toim), Immigrant Languages in Europe. Clevedon, PhiladelphiaAdelaide: Multilingual Matters, lk 197-221.

J o h a n s o n, Lars 2002a. Contact-induced linguistic change in a code-copying framework. - M. C. Jones, E. Esch (toim), Language Change: The Interplay of Internal, External and Extra-linguistic Factors. Contributions to the Sociology of Language, kd 86. Berlin: Mouton de Gruyter, lk 285-313.

J o h a n s o n, Lars 2002b. Structural Factors in Turkic Language Contacts. London: Curzon.

Ke evallik, Leelo. 2006a. Keelekontakt ja pragmaatika. - I. Tragel, H. Õim (toim), Teoreetiline keeleteadus Eestis II. (TÜ Üldkeeleteaduse õppetooli toimetised 7.) Tartu: Tartu Ülikooli Kirjastus, lk 85-96.

Keevallik, Leelo 2006b. Pragmaatiliste partiklite laenutüübid rootsieesti keeles. - Mitmõkeelisüs ja keelevaihtus Õdagumeresoomõ maiõ pääl. Toim H. Koks, J. Rahman. (Võro Instituudi toimõndusõq 18.) Võro, lk 116-133.

M a s c h le r, Yael 1994. Metalanguaging and discourse markers in bilingual conversation. - Language in Society, kd 23, nr 3, lk 325-366.

M a tr a s, Yaron 1998. Utterance modifiers and universals of grammatical borrowing. - Linguistics, kd 36, nr 2, lk 281-331.

M a tr a s, Yaron 2005. The full extent of 'fusion': a test case for connectivity and language contact. - W. Bisang, T. Bierschenk, D. Kreikenbom, U. Verhoeven (toim), Kulturelle und sprachliche Kontakte: Prozesse des Wandels in historischen Spannungsfeldern Nordostafrikas/Westasiens. Akten zum 2. Symposium des SFB 295. Würzburg: Ergon Verlag, lk 241-255.

M a tr a s, Yaron 2009. Language Contact. Cambridge, New York: Cambridge University Press.

M a tra s, Yaron. 2012. An activity-oriented approach to contact-induced language change. - C. Chamoreau, I. Léglise (toim), Dynamics of Contact-Induced Language Change. Berlin: Mouton de Gruyter, lk 17-52. 
M a tr a s, Yaron, S a k e l, Jeanette 2007. Investigating the mechanism of pattern replication in language convergence. - Studies in Language, kd 31, nr 4, lk 829865.

M e t s l a n g, Helle. 2006. Predikaat ajastut kogemas. - Keel ja Kirjandus, nr 9, lk 714-727.

Montrul, Silvina 2010. Current issues in heritage language acquisition. Annual Review of Applied Linguistics, kd 30, lk 3-23.

M u h a m e d ow a, Raihan 2009. The use of Russian conjunction in the speech of bilingual Kazahks. - International Journal of Bilingualism, kd 13, nr 3, lk 331356.

Muysken, Pieter 1995. Code-switching and grammatical theory. - L. Milroy, P. Muysken (toim), One Speaker, Two languages. Cambridge: Cambridge University Press, lk 177-198.

Muysken, Pieter 2000. Bilingual Speech: A Typology of Code-mixing. Cambridge: Cambridge University Press.

M ye r s-S c ott o n, Carol 2002. Contact Linguistics: Bilingual Encounters and Grammatical Outcomes. Oxford: Oxford University Press.

P a lj a s m a, Veronika 2012. Prantsuse-eesti koodikopeerimine blogides. Magistritöö. Tallinn: Tallinna Ülikooli Eesti keele ja kultuuri instituut.

$\mathrm{P}$ a v le n k o, Aneta 2005. Emotions and Multilingualism. Cambridge: Cambridge University Press.

Pr a a k li, Kristiina 2009. Esimese põlvkonna Soome eestlaste kakskeelne keelekasutus ja koodikopeerimine. (Dissertationes philologiae Estonicae Universitatis Tartuensis 24.) Tartu: Tartu Ülikooli Kirjastus.

S a l m o n s, Joseph 1990. Bilingual discourse marking: code switching, borrowing and convergence in some German-American dialects. - Linguistics, $\mathrm{kd} 28, \mathrm{nr} 3$, lk 453-480.

Z abrodskaja, Anastassia 2009a. Evaluating the Matrix Language Frame model on the basis of a Russian-Estonian codeswitching corpus. - International Journal of Bilingualism, kd 13, nr 3, lk 357-377.

$\mathrm{Z}$ a b r od s k aj a, Anastassia 2009b. Russian-Estonian language contacts: grammatical aspects of language use and change. $\mathrm{PhD}$ dissertation. Tallinn: Tallinna Ülikooli Kirjastus.

Th o m a o n, Sara Grey 1997. On mechanisms of interference. - S. Eliasson, E. H. Jahr (toim), Language and its Ecology: Essays in Memory of Einar Haugen. Berlin, New York: Mouton de Gruyter, lk 181-207.

Th o m a s o n, Sarah Grey 2003. Contact as a source of language change. - R. D. Janda, B. D. Joseph (toim), A Handbook of Historical Linguistics. Oxford: Blackwell, lk 687-712.

Va b a, Marja 2010. Inglise-eesti koodikopeerimisest Skype’i Tallinna kontori kahe vestlusgrupi näitel. Magistritöö. Tallinn: Tallinna Ülikooli Eesti keele ja kultuuri instituut.

Va b a, Marja 2011. Inglise-eesti koodikopeerimise kommunikatiivsest aspektist Skype'i Tallinna kontori näitel. - A. Matteus, A. Zabrodskaja (toim), Noored filoloogid kirjanduse ja keele piirimail. Tallinn: TLÜ eesti keele ja kultuuri instituut, lk 386-387.

Ve r s c hik, Anna 2004. Estonian compound nouns and their equivalents in the local variety of Russian. - Scando-Slavica, kd 50, lk 93-109. 
Vers c hik, Anna 2007. Keelekontaktid, laenatavus ja verbi kopeerimine eestivene keelevariandis. - Keel ja Kirjandus, nr 5, lk 257-277.

W e i n r e i c h, Uriel 1953. Languages in Contacts. The Hague: Mouton.

Wertheim, Suzanne 2003. Linguistic Purism, Language Shift and ContactInduced Change in Tatar. Ph. D. dissertation, University of California, Berkeley.

\section{The Beauty (and Use) of the Study of Language Contacts}

Keywords: contact-induced language change, code copying, PAT- and MAT-replication

The article clarifies the importance of contact linguistics in the Estonian context. It is argued that the current sociolinguistic situation is highly relevant for a general contact linguistic research (small size of the country, different linguistic communities, post-Soviet changes in language policies and, subsequently, bilingualization of Russian-speakers, and arrival of English as a new agent on the contact scene). Two recent contact-induced language change models are introduced and compared: the code-copying framework by L. Johanson and the PAT- and MATreplication model by J. Matras and J. Sakel. The former has been used in the Estonian situation by several researchers. The models share several common features: a holistic, non-constrained approach to language contact phenomena, the same mechanisms (copying/replication) for all language levels (rather than separate models for code-switching and morhposyntactic changes). The latter model is more concerned with functional and cognitive reasons of replication, placing the major site of change into individual speakers. At a descriptive level, Johanson's code-copying framework appears more accurate since a category of mixed copying is introduced there. Data from Russian-Estonian and EnglishEstonian language contacts support the relevance of mixed copying.

Anna Verschik (b. 1968), PhD, Tallinn University, Institute of Estonian Language and Culture, professor of general linguistics, annave@tlu.ee 